\title{
The People and the Making of India's Constitution
}

\author{
Ornit Shani \\ Department of Asian Studies, University of Haifa, Haifa, Israel \\ Email: shanio@research.haifa.ac.il
}

\begin{abstract}
This article explores the engagements of people and various civic organizations, even from the margins of society, with the making of India's constitution during the early stages of its drafting. Using hitherto unstudied archival materials, it examines constitutional visions, demands, conceptions of inclusion, and constitutional proposals, as these were expressed at the time by people outside of the Constituent Assembly. The conventional understanding has been that the constitution was a product of elite consensual decision-making, and that India's nationalist leaders endowed it from above. This article shifts the historical inquiry away from the Constituent Assembly onto the ways the constitution-making process was experienced, related to, and understood from below by 'We the People' - those on behalf of whom the constitution would ultimately be enacted. Hence, it constructs a new perspective on the making of India's constitution. In doing so, the article throws light on the significance of people's interactions with the constitution-making process on the nature of India's decolonization, on its successful democratic transition, and on the rooting and endurance of its constitution against many odds.
\end{abstract}

On 22 November 1946, just before the beginning of the Indian Constituent Assembly debates, one Mr Inder Lal, a retired official from Saharanpur in the United Provinces, sent a fifty-five page document to the secretary of the Constituent Assembly: 'The basic principles of the Indian constitution (for permanent constitution) or a memorandum to the Indian Constituent Assembly'. It was composed of eleven chapters and an appendix that summarized the 'Chief Merits' of his constitutional proposal. Mr Lal wrote in the introduction that his proposal forms an attempt 'to reconcile the various warring elements in the cultural, economic, and political life of the country'.2

\footnotetext{
${ }^{1}$ Inder Lal, 22 Nov. 1946, New Delhi, National Archives of India (NAI), CA/19/47/1947 Cons I.

${ }^{2}$ Ibid., p. 2.
} 
Mr Lal requested that his memorandum be "circulated, as soon as possible, among all the members of the Indian Constituent Assembly...and also to get it published along with the final Report of the Indian Constituent Assembly'. The secretary of the Constituent Assembly (CA) informed Mr Lal that his office was unable to circulate his memorandum to the assembly, or to get it published. At that time, the Indian CA had not even met. It convened for the first time on 9 December 1946. Persisting, Mr Lal wrote again a few weeks later. This time, he addressed his proposal directly to the newly appointed president of the CA, Rajendra Prasad. Referring to this letter, the secretary of the CA commented: 'We have received, and continue to receive, similar memoranda from other persons also with the request that they may be printed and circulated to members, so that if one request is acceded to, it will be difficult to refuse others. ${ }^{4}$

Indeed, a historical inquiry into previously unexplored archival materials reveal that Mr Lal was one of many individuals and multifarious organizations that addressed the secretariat of the $\mathrm{CA}$, its president or the constitutional adviser, B. N. Rau, with schemes, opinions, and suggestions for the future constitution of India. The Indian CA, which was entrusted with the task of writing a constitution for free India, enacted the constitution on 26 January 1950 after three years of deliberation between December 1946 and November 1949. Between August 1946 (three months before the CA convened for the first time) and October 1947, when the first draft constitution was ready, at least fifty individuals and a dozen organizations submitted suggestions and elaborate proposals for the constitution of India. In addition, at least 150 organizations and a dozen individuals wrote to the $\mathrm{CA}$ and its president with requests for representation of their group, religion, caste, tribe, or profession in the assembly's advisory committee, or with demands to be recognized as minorities in the constitution. They often submitted detailed suggestions for constitutional means of safeguarding their minority rights. People's engagement with the drafting of the constitution continued throughout the three years of this process.

This article explores the engagements of people and various civic organizations with the constitution-in-the-making during the early stages of its drafting, and even just prior to the convening of the CA. Using hitherto unstudied archival materials, it examines constitutional visions, aspirations, demands, conceptions of inclusion, and constitutional proposals, as these were expressed at the time by individuals and by diverse organizations. The article argues that people's expressions of aspirations, and the solutions they envisioned and proposed for the various constitutional problems of India, produced a popular constitutional language and an awareness of being rights-bearing citizens, which asserted the constitution's relevance to them, and contributed to its legitimation ahead of its enactment.

The active engagement of people and groups, even from the margins of society, with visions for the future constitution, and the claims they made

\footnotetext{
${ }^{3}$ Inder Lal to the secretary of the Indian Constituent Assembly (CA), 22 Nov. 1946, NAI, CA/38/ Gen/46.

${ }^{4}$ H. V. R. Iengar, 22 Jan. 1947, NAI, CA/19/47/1947 Cons I, s. no. 6.
} 
in the pursuit of their aspirations of the Constituent Assembly, has been an unexplored facet in the study of the history of India's constitution-making. ${ }^{5}$ Overall, there are few legal-historical studies on the involvement of the public with constitution-drafting processes. ${ }^{6}$ It is only recently that the importance of public participation in constitution-making has gained recognition among historians and legal scholars. ${ }^{7}$ The accepted wisdom at the time of decolonization in Asia and Africa was that constitutions were best written by foreign experts behind closed doors and even by colonial officials ahead of their departure. Indians wrote their constitution for themselves.

The creation of a democratic constitution in India in the late 1940s was at odds with the requisite conditions prescribed by democratic theory, and many at the time predicted that it would not succeed. In successfully institutionalizing a democratic constitution and creating the world's largest democracy, India defied many naysayers. The Indian constitution has turned out to be the longest-living constitution in the post-colonial world. This was not inevitable, and there was no certainty that India's democracy would succeed. The Indian case, with the engagement of the forming demos in the making of the constitution from below, is instructive more broadly for the question of constitutional endurance and democratic theory at large, especially for sizeable, diverse societies.

\footnotetext{
${ }^{5}$ A few scholars have noted that there were numerous responses from the public to the drafting of the constitution, but these were not explored thus far. See Granville Austin, The Indian constitution: cornerstone of a nation (New Delhi, 2006; 1st edn 1966), p. 324; Ramachandra Guha, India after Gandhi: a history of the world's largest democracy (London, 2007), pp. 105, 789 (n. 5); Rohit De, A people's constitution: the everyday life of law in the Indian Republic (Princeton, NJ, 2018), pp. 2, 235 (n. 5); and Arvind Elangovan, 'The making of the Indian constitution: a case for a non-nationalist approach', History Compass, 12 (2014), pp. 1-10; idem, Norms and politics: Sir Benegal Narsing Rau in the making of the Indian constitution, 1935-1950 (New Delhi, 2019), p. 231 n. 36. Elsewhere, I examine responses of the public to the draft constitution in relation to the preparation of the electoral rolls on the basis of universal franchise. See Ornit Shani, How India became democratic: citizenship and the making of the universal franchise (Cambridge, 2018).

${ }^{6}$ For some of these exceptions, see, for example, Steven Wilf's explorations of popular law talks, and of how people read, in the main, criminal law after the American Revolution. Steven Wilf, Law's imagined republic: popular politics and criminal justice in revolutionary America (Cambridge, 2010). Assaf Likhovski recently examined constitutional proposals sent by the public to the Constitution Committee of the Provisional State Council of Israel in 1948, which ultimately failed to produce a constitution. Assaf Likhovski, 'The rise and demise of constitutional duties in Israel', American Journal of Legal History, 61 (2021), pp. 90-120. Linda Colley's recent global history of constitutionmaking from the mid-eighteenth century stresses emphasis on voices from below that drove demands for rights and constitution-writing. Unlike in the case of India, however, Colley connects constitutions writing from that time to shifting patterns of war and violence. She suggests that the people who drove these processes from below were those affected by these shifts, especially soldiers. Linda Colley, The gun, the ship and the pen: warfare, constitutions and the making of the modern world (London, 2021). The scale and depth of engagements of the public with the constitutionmaking process discussed in this article posit a challenge to the notion that constitutions come into being by charismatic leaders. See Bruce Ackerman, Revolutionary constitutions: charismatic leadership and the rule of law (Cambridge, MA, 2019).

${ }^{7}$ See, for example, Hanna Lerner and David Landau, 'Introduction to comparative constitution making: the state of the field', in David Landau and Hanna Lerner, eds., Comparative constitution making (Cheltenham, 2019), pp. 1-25; and Wilf, Law's imagined republic, pp. 3-4.
} 
The conventional understanding has been that the Indian constitution was a product of elite consensual decision-making, and that India's nationalist leaders endowed it from above. The constitution was described as 'a gift of a small set of India's elites. ${ }^{8}$ Working on this sometimes implicit assumption, studies of the making of the Indian constitution have focused on the voluminous constitutional debates as their principal source of inquiry. They examined the ethical vision, political theory, ideas underlying key constitutional provisions, and prior constitutional frameworks, proposals, and laws that informed those deliberations. ${ }^{9}$ Scholars have on the whole also held the view that the 'people' had little or no involvement in the process of constitution-making, and that this process did not occupy the concerns of ordinary Indians. ${ }^{10}$ Perhaps the long settled underlying assumption that the constitution was a product of elite decision-making narrowed the scope of research, and by extension, the sources on which scholars relied. The extensive constitutional debates became the canon for constitutional inquiries. Under the conditions of India's independence, amid the large-scale violence of the partition, high levels of illiteracy and poverty, and a society deeply divided by caste, linguistic, and religious lines, this view appeared plausible to political thinkers and legal historians.

Recent studies disrupt this narrative. In A people's constitution, for example, Rohit De shows that people, including those from the social margins, related to the constitution and used it to find solutions to their problems within months of its enactment. ${ }^{11}$ The speed with which this happened calls into question the notion that people were bystanders when the constitution was being drafted. Indeed, in the context of the preparations of the first draft electoral rolls on the basis of universal franchise, from March 1948, in anticipation of the constitution, people engaged with the draft constitutional provisions that related to franchise, while they struggled to secure their place on the roll. ${ }^{12}$

Building on these findings, this article, thus, shifts the historical inquiry away from the CA onto the ways the constitution-making process was experienced, related to, and understood from below by 'We, the People' - those on behalf of whom the constitution would ultimately be enacted. Hence, it

\footnotetext{
${ }^{8}$ Sunil Khilnani, 'Arguing democracy: intellectuals and politics in modern India', Centre of the Advanced Study of India Working Paper Series, University of Pennsylvania, 2009, 26. Also see Sunil Khilnani, The idea of India (London, 1997), pp. 34-5.

${ }^{9}$ See, for example, Austin, The Indian constitution; Rajeev Bhargava, ed., Politics and ethics of the Indian constitution (New Delhi, 2008); Rochana Bajpai, Debating difference: group rights and liberal democracy in India (New Delhi, 2011); Uday S. Mehta, 'Indian constitutionalism: crisis, unity, and history', in Sujit Choudhry, Madhav Khosla, and Pratap Bhanu Mehta, eds., The Oxford handbook of the Indian constitution (Oxford, 2016), pp. 38-54; Aditya Nigam, 'A text without author: locating Constituent Assembly as event', Economic and Political Weekly, 39 (2004), pp. 2107-13; Udit Bhatia, ed., The Indian Constituent Assembly: deliberations on democracy (London, 2018); Gautam Bhatia, The transformative constitution: a radical biography in nine acts (Noida, 2019); Madhav Khosla, India's founding moment: the constitution of a most surprising democracy (Cambridge, 2020).

${ }^{10}$ Khilnani, 'Arguing democracy', 26.

${ }^{11}$ De, A people's constitution; idem, 'Beyond the social contract', Seminar, 615 (2010).

${ }^{12}$ See Shani, How India became democratic, ch. 3, and for the influence of these public engagements on the final constitutional provisions on elections, see ch. 5 .
} 
constructs a new perspective on the making of India's constitution. In doing so, the article does not trace the impact of these engagements on specific final constitutional outcomes. ${ }^{13}$ Instead, it throws light on the significance of people's interactions with the constitution-making process on the nature of India's decolonization, on its successful democratic transition, and on the rooting of its constitution against many odds.

It was indeed not self-evident that under the adverse conditions of independence a constitution based on the principle that sovereignty is derived from the people would strike roots, resonate with Indians, or that it would endure. The becoming of the people was to emerge out of a colonized, illiterate, and poor society, deeply divided by caste, language, and religion. There were also nearly 90 million people living in 552 princely states spread across the subcontinent that were not part of British India, and that were yet to be integrated into the new Union. Some of these states were in the process of establishing their own constituent assemblies. Some states already drafted constitutions for themselves. ${ }^{14}$ Moreover, the CA's legitimacy as a constitutionmaking body was not beyond dispute. The legislative assemblies of the provinces of British India chose the members of the Indian CA. These were themselves elected in the 1946 elections on the basis of a very limited franchise that was structured along religious, community, and professional lines according to the 1935 Government of India Act, the last colonial constitutional framework for India. Indian leaders and political parties resisted fiercely the 1935 colonial constitution. ${ }^{15}$ Furthermore, when the assembly convened, six months before the declaration of the partition of India and Pakistan, about a third of its prospective members - representatives of the Muslim League and from the princely states - did not take part. In this context of decolonization, an all-India constitution based on the principle of a government of the people by the people bestowed from above would not as a matter of course have gained enough credence to ensure that Indians would identify with it and understand that it applied to them once it came into force.

It was through the interactions between people and the CA, I suggest, that people began to gain ownership over the future constitution, and to assert themselves as the soon to be sovereign-subjects, not as subordinated colonial subjects. At the same time, they lent legitimacy to the constitution-making body. The individuals and organizations that engaged with the constitution-in-the-making from the outset, and that made claims of the CA, did so at their own initiative. There is no indication that the CA originally

\footnotetext{
${ }^{13}$ People's engagements with the draft constitution effected, for example, radical changes to the final constitutional provisions on the direction and control of elections. See ibid., pp. 184-92.

${ }^{14}$ See, for example, Shani, How India became democratic, pp. 125-6, 149-50, 172-4. For a new history of the making of India's constitution that stresses emphasis on the broader influences on the constitution-making from outside the $\mathrm{CA}$, including the processes of constitution-making in the princely states, see Rohit De and Ornit Shani, 'From founding to assembling: towards a new history of India's constitution making' (forthcoming).

${ }^{15}$ The 1935 Government of India Act contained no provisions for fundamental rights. It is also noteworthy, however, that the Indian constitution ultimately incorporated roughly two-thirds of the Act.
} 
planned to solicit public inputs. The colonial state sometimes invited the views of leading officials and even non-official sources while planning for important legislation. Thus, there were apparently precedents for the practice. There has been also a long and rich history of petitioning to the ruler in power on the subcontinent. But the colonial regime sought, in the main, the views of specified groups and leading individuals, and their invited opinions were limited in their scope a priori by set terms of reference and defined lists of topics. Similarly, public petitions were largely limited to pleas made to the colonial rulers over narrow grievances. ${ }^{16}$

The memoranda and schemes for a constitution for India came from across the country, and dealt with disparate issues. ${ }^{17}$ Some individuals and organizations wrote more than once. A few also published their suggestions in newspapers, or distributed a large number of copies they printed. The secretariat of the CA acknowledged the receipt of all letters by return mail. In these iterative processes and constitutional correspondences, people manifested themselves at once as the authorizing agents of the constitution and its reconstituted subjects. ${ }^{18}$ Thus, it was through the constitution-making process that people constituted themselves both as individuals and as members of communities. Their anticipation of a constitution based on universal adult franchise allowed them to invoke old and new collective identities, and to make claims on that basis. This heralded challenges that would later continue to beset the democratic life of the Republic and that originated in this process of decolonization.

The archival records on which this article is mainly based contain at least sixteen thick folders preserving letters, telegrams, proposals, pamphlets, and memoranda 'relating to Constitution Making' that were received at the CA from private individuals and associations. ${ }^{19}$ With the exception of a small

${ }^{16}$ The Indian Statutory Commission (the Simon Commission), for example, invited submissions from both official and non-official sources on the basis of a list of subjects. The volume of its report that contains such submissions does not include any unsolicited representations from ordinary people. See Report of the Indian Statutory Commission volume XVII (London, 1930). For a comprehensive discussion of the history of petitioning in South Asia and its many facets, see 'Petitioning and political cultures in South Asia', Modern Asian Studies, 53 (special issue, ed. Rohit De and Robert Travers) (2019).

${ }^{17}$ Letters arrived, for example, from Ahmedabad, Ahmednagar, Alipur, Allahabad, Ambala, Benares, Berhampur, Bezwada, Bombay, Calcutta, Dacca, Dibrugarh, Coorg, Gauhati, Indore, Lucknow, Ludhiana, Lyallpur, Madurai, Nagpur, New Delhi, Nowgong, Patna, Poona, Raikwar, Saharanpur, Silchar, Simla, Surat, Sylhet, Tanjore, Tindivanam, and even from remote areas like the Chittagong Hill Tracts, Darjeeling, and the Lushai Hills.

${ }^{18}$ Here I draw on Uday Mehta's proposition that 'Constitutional founding moments express that inescapable circularity in which they are authorised by the people, but which, by the structures that constitutions put in place, reconstitute the people as subjects.' Mehta, 'Indian constitutionalism: crisis, unity, and history', p. 38.

${ }^{19}$ I first discovered files from the CA secretariat in 2010, while working on How India became democratic at the election commission of India record room. On that basis, I started later to trace more files from the secretariat, which I found at the NAI. I could not verify exactly when these files arrived at the NAI. They were clearly reviewed in 1989, and were marked as 'to keep', though some items were marked as 'destroy', but were kept nonetheless. An index of these files was prepared in 2005. 
number of letters in vernacular languages, all letters, telegrams, and proposals were written in English. Some were handwritten. Very few letters came from women; these included two letters from women's adivasi (tribal) organizations. ${ }^{20}$ These records are absent from earlier accounts of India's constitutionmaking. This archive is not without its limitations. An absence of certain voices, such as those of women, is indicative of the archive's shortcomings and does not necessarily mean that women were silent. The All-India Women's Conference, for example, discussed and passed resolutions on the future constitution-making body from early 1946; and during the Constituent Assembly debates in 1948-9, its members campaigned for a Hindu code bill, and sent a deputation to Delhi to meet with members of the assembly. ${ }^{21}$

In piecing together a hitherto unknown facet of the making of the Indian constitution, this article also broadens our understanding of the way a democratic constitutional order came about and endured. The question of popular adherence to the constitutional method 'on an Indian soil, which is essentially undemocratic' was a deep concern of the chair of the CA's drafting committee, B. R. Ambedkar. ${ }^{22}$

The first section examines proposals for the future constitution of India that people and various organizations sent to the CA at the early stages of constitution-making. It demonstrates the breadth of constitutional concerns that animated people's imagination, and their efforts to take part in the constitutional conversations. The second section looks at people's efforts, and especially of groups from the social margins, to self-organize and claim special recognition, and to influence the process of determining groups' rights during the beginnings of the constitutional debates. Across the two sections, I also show how people's engagements with the constitution became part of broader popular constitutional conversations that surrounded the making of the Indian constitution and that took place outside the walls of the Constitution Hall. The article, thus, indicates the significance of the larger processes and contexts within which the constitution, its language, and its making became part of the Indian imagination.

Pamphlets and memoranda relating to constitution-making arrived at the secretariat of the CA from August 1946 onwards. Their senders put forward a wide range of imaginative constitutional suggestions and expressed some prescient concerns. In the main, their proposals aimed, as they often stated, to ensure

${ }^{20}$ The secretary of the Singh Bhum Adibasi Mahila Sangh, Chaibasa, to the president of the CA, 5 Feb. 1947, NAI, CA/27/Com/47.

${ }^{21}$ The All-India Women's Conference Eighteenth Session, December 28th 1945 to January 1st 1946, Hyderabad (Bombay, 1946), p. 73; The All-India Women's Conference Silver Jubilee Session, May 2nd to 5th, 1953, Poona (New Delhi, 1953), p. 181. Also see Kamala Devi Chattopadhyay, The status of women in India (Group E: Women's problems), Asian Relations Conference, Mar.-Apr. 1947 (New Delhi, 1947), pp. 14, 16.

${ }^{22}$ See Constituent Assembly Debates (CAD), 4 Nov. 1948, http://164.100.47.194/Loksabha/Debates/ cadebadvsearch.aspx, accessed 23 Mar. 2020. 
that democracy be 'placed on a secure footing. ${ }^{23}$ Organizations and individuals proposed schemes for a 'Workable constitution for free and democratic India', which 'provides the adequate safeguards for every Indian however weak or backward he may be', ${ }^{24}$ for 'How to make the working of the Indian constitution successful', ${ }^{25}$ or noted points that 'must always be kept in view' in 'drawing up any constitution for India'. ${ }^{26}$ There were only two schemes for a non-secular India on a 'Theocratic basis of the State as distinguished from the secular "Will of the People" Basis. ${ }^{27}$ The proposed constitutional visions for a secure and democratic India drew attention to distinct aspects of the country's problems and suggested solutions for them in the future constitutional order. They also held different views on rights, liberty, and equality.

Several letters offered a vision for a constitution that would provide scope for transformative social reforms. Their authors dealt with views and means of reconciling the aspirations for democracy with the social conditions of a society deeply divided by caste, community, and religion, and with nation-state building more generally. The Ved Parchar Mandal from Lyallpur, for example, submitted ahead of the convening of the CA a twenty-four-point proposal, which described what the future constitution ought to be: "free from any kind of communalism and religious interference', and based on equality and justice. 'There should be no state religion'; 'Up-to-date means and measures should be devised to develop agriculture'; 'adult franchise based on joint electorates and no weightage'; 'Nobody should be compelled to pay any court fees to apply for the right of votership'; free and compulsory primary education; legalize inter-dining and inter-marriage between different castes; abolition of untouchability, Sati, child marriage, and the restrictions on entry to public worship places. ${ }^{28}$

The question of the relations between the state and religion, and the problem of social inequality, occupied many memoranda. One requested for the 'State to be non-denominational', and that in recognition of India's multireligious society, to only allow "legislation in matters relating to religious and social matters of any community', if approved by a threshold of 66 per cent vote of legislators of that community, 'except when the matter is one of repugnent [sic] to public morality or policy'. ${ }^{29}$

\footnotetext{
${ }^{23}$ M. S. V. Chari to B. N. Rau, 14 May 1947, NAI, CA/19/47/1947 Cons II.

${ }^{24}$ Kishan Lal Joshi, 'Workable constitution for free and democratic India', received on 28 Jan. 1947, NAI, CA/19/47/1947 Cons I.

${ }^{25}$ Jagan Nath, member Communal Harmony Board, Jagadhari, to the secretary of the CA, 30 Oct. 1947, and 22 Nov. 1947, NAI, CA/19/47/1947 Cons II.

${ }^{26}$ Ram Ratan, Ludhiana, to B. N. Rau, 31 Mar. 1947, NAI, CA/19/47/1947 Cons I.

${ }^{27}$ V. R. Dholakia, secretary of the All India Dharma Sangh, Indian Constitution Committee, undated, NAI, CA/38/Gen/46.

${ }^{28}$ Vishwa Mitra, secretary of the Ved Parchar Mandal (the organization for disseminating the words of the Veda) to the members of the CA and legislatures, 1 Aug. 1946, NAI, CA/19/47/1947 Cons II.

${ }^{29}$ Sree Manikonda Satyanarayana Sastry, 'Fourteen-point memorandum for the future constitution of India', to the CA, 18 Sept. 1946, NAI, CA/38/Gen/46.
} 
Most of the schemes for the future constitution were based on a positive view of rights, which conceived of the new state as an agent of social change through the guarantee of various provisions for the promotion of equality, and legal protections for minorities. A few proposals, however, argued for the protection of India's social structures from legal interference, based on a negative conception of rights, whereby the state guarantees the freedom of the individual from state interventions. Thus, in a ten-page memorandum, 'The social structure of India \& power of legislation', Mr K. V. Sundaresa Iyer suggested that if the constitution would 'provide certain amount of immunity and protection for communal customs and culture, from unjust statutory interference, every community will thereby be assured of its "stan" notionally, if not geographically' ${ }^{30} \mathrm{Mr}$ Iyer suggested restrictions on legislations in social matters. Thus, he argued, 'Where is individual freedom if Harijans [former untouchables, dalits] must be received and served in all hotels?' And 'What is the justification for the Government to step into' the field of inter-dining, or dowry, which is 'a purely personal and economic question' ${ }^{31}$ It was from a liberal negative rights perspective that $\mathrm{Mr}$ Iyer exhorted the members of the CA to 'realise that they are now supplying arms to future legislatures. Now is the time for them to see that the these [sic] arms will not be used against the people. $^{32}$

The constitutional concerns of many individuals and organizations also included the question of the future federal structure and its implications for the unity of India. During the months that preceded the declaration of the partition plan of June 1947, and in anticipation of the convening of the CA, people analysed at length the possible implications of the impending partition for the constitution and presented concrete suggestions. The memorandum 'Fundamental law of the Indian Union (No. I)', set out a constitutional scheme for three federations and one union: Hindustan, West Pakistan, and East Pakistan. ${ }^{33}$ It was based on the principle that 'India cannot remain united unless it is fully prepared to be divided', and that a creation of a union requires also to establish the right of secession. ${ }^{34}$

Following the fast-changing circumstances with the declaration of the partition plan on 3 June 1947, people and organizations stressed the importance of a strong federal structure. A document entitled 'Suggestion re: the constitution of the Indian Union' stated that 'it is absolutely necessary to have a strong and unified centre so that it is able to keep in check all fissiparous tendencies which have been the cause of the downfall and disunity of the Hindus'. ${ }^{35}$

${ }^{30}$ K. V. Sundaresa Iyer, 'The social structure of India \& the power of legislation', 1947, NAI, CA /19/ 47/1947 Cons II.

${ }^{31}$ Ibid., pp. 8-9.

${ }^{32}$ Ibid., p. 10.

33 'Fundamental law of the Indian Union (No. I)' (name of author illegible) to the secretary of the CA, H. V. R. Iengar, 30 Nov. 1946, NAI, CA/19/47/1947 Cons I.

${ }^{34} \mathrm{Ibid}$.

35 'Suggestion re: the constitution of the Indian Union' (author's name illegible), 9 July 1947, NAI, CA/19/47/1947 Cons II. 
The document presented, accordingly, a detailed list of the subjects that should be administered by the central and provincial governments.

Many of the proposals grappled with additional aspects for a constitutional design that would ensure unity in the midst of the great social diversity of the country, like the question of language and the structure of the administration. The memorandum 'The basic principles of the Indian constitution' suggested that 'the only correct solution for the language problem is that every Linguistic and Cultural Unit...should have the liberty to use its own vernacular', and that English should be continued to be used for inter-provincial and Central Government purposes' until any other decision by mutual consent. ${ }^{36}$ It is noteworthy that this suggestion, just ahead of the beginning of the constitutional debates, was largely in line with the final constitutional provisions on the language of the Union and regional languages, which was a much disputed subject in the assembly.

People had suggestions for overcoming linguistic and cultural divides through new administrative structure for India. One Mr Oak proposed a 'Scheme for the future administration of Independent India', laying out a plan for dividing India into 'administrative squares or areas (or units) cut off by longitudes and parallels of latitude (Map attached)' ${ }^{37}$ Mr Oak claimed that this scheme would hasten 'the death of our linguistic and other differences...leading to the ultimate unity of all Indians' ${ }^{38}$ He also suggested that 'this system will be very convenient for computing statistics or collecting data....surveying etc. ${ }^{39}$

People and various organizations from across the country were not passive observers of the making of the constitution. They had visions and ideas about the future constitution, and about what it and the new state ought to be. They articulated their thoughts and suggestions in writing, and made efforts to convey these to the members of the CA, and to be heard. Some demanded to circulate their proposals among the members of the assembly and prepared free copies. People expressed a clear sense of having a stake in both the constitution and in its making. Most proposals for the future constitution arrived at the CA secretariat before the CA established the drafting committee on 29 August 1947.

Moreover, from August 1946 onwards, people's and various organizations' views on the future constitution appeared regularly in newspapers. 'Readers' Views', and 'To the Editor' sections addressed regularly the future constitution, commenting on subjects such as untouchability, the status of the people living in the princely states, and the federal structure. ${ }^{40}$

\footnotetext{
${ }^{36}$ Inder Lal, 'The basic principles of the Indian constitution (for permanent constitution) or a memorandum to the Indian Constituent Assembly', 22 Nov. 1946, NAI, CA/19/47/1947 Cons I, pp. 5-6.

${ }^{37} \mathrm{P}$. N. Oak to the secretary of the CA, 'Scheme for the future administration of Independent India', 24 Apr. 1947, NAI, CA/19/47/1947 Cons I.

${ }^{38} \mathrm{Ibid}$.

${ }^{39} \mathrm{Ibid}$.

${ }^{40}$ See, for example, 'Anti-untouchability laws', Times of India (TOI), 16 Oct. 1946, p. 4; 'Status of states' people', TOI, 29 Oct. 1946, p. 6; 'The tree-tier constitution', TOI, 28 Nov. 1946, p. 6.
} 
During the early days of the CA, people's constitutional meditations were set against the looming crisis of the partition, and the consequent uncertainty about basic constitutional questions, such as the nature of the federations and the relations between the states and the centre. As evidenced by the account of people's constitutional schemes and ideas, many of their concerns were similar to those that occupied the constitution-makers and that subsequently dominated the assembly debates: the unity of India, and social issues in the face of the country's great social diversity and deep divisions. Some of the people's concerns reflected questions that became enduring constitutional conundrums, such as the relations between religion and the state, and contested conceptions of how to promote equality and how to counter discrimination based on caste.

Among the individuals who sent schemes for the future constitution there were a few retired and one active civil servant, and a few advocates. ${ }^{41}$ There were also a few members or former office-holders of various organizations among the senders. Among these were, for example, an ex-president of the World Youth League, a member of a Communal Harmony Board, a member of the Bengal Pradesh Congress Committee, and an ex-assistant secretary of the All India Young Men's Association. There were also among them individuals who defined themselves as, for example, ordinary people, or as a 'citizen of the free India'. ${ }^{42}$ One writer concluded his letter: 'In the end I appeal to you to consider this plan in its aspects and not to neglect merely because it is suggested by an ordinary man. ${ }^{43}$ Two months after he received an acknowledged receipt of his proposal for a 'Workable constitution', he sent it again, now to a member of the assembly stating:

I feel that when I have to offer to the house and through the house to the country something for the welfare of my countryman I should take part in the deliberation of the Constituent Assembly and explain the urgency and importance of the whole or any of the points mentioned briefly in the Constitution referred to above. ${ }^{44}$

Another person wrote to B. N. Rau, asking to put his scheme before the assembly while it was going to be in session on 16 April 1947. He noted: 'I am not a politician but a Chemical Engineer. This is only an idea and I don't lose status if it is not conducive to the Constituent Assembly. If acceptable to the Assembly, further details on the scheme could be considered. ${ }^{45}$ The tone of some letters

${ }^{41}$ See, for example, R. S. Chabukswar, Retd. Nazir, Judicial Department at Rahuri Dt. Ahmednagar Bombay Province to Jawaharlal Nehru, 'A draft for Indian constitution', 5 May 1947, NAI, CA/19/47/1947 Cons I.

${ }^{42}$ Sujit Chatterjee to the president of the CA, 22 Sept. 1947, NAI, CA/19/47/1947 Cons II.

${ }^{43}$ Kishan Lal Joshi, 'Workable constitution for free and democratic India', received on 28 Jan. 1947, NAI, CA/19/47/1947 Cons I.

${ }^{44}$ Kishan Lal Joshi to Dr B. Pattabhai Sitaramayya, 23 Mar. 1947, New Delhi, Nehru Memorial and Museum Library (NMML), All India States' People's Conference papers, F. 249, 1946-8. Emphasis added.

${ }^{45}$ Jandhyala Krishnanandam to Sir B. N. Rao (sic), 'Scheme for unification of India for political advancement’, 6 Mar. 1947, NAI, CA/19/47/1947 Cons I. 
was almost imperative. Authors asserted that the assembly 'should provide...', or 'should define.... ${ }^{46}$ One person even suggested that the debates of all the legislative assemblies 'should be made available to masses and other public libraries'. ${ }^{47}$ Thus, at least some of the letter writers acted seemingly on the assumption that the constitution-makers were accountable to them.

Indeed, people expected to receive a response to their letters and proposals. Some of them asked explicitly to be informed 'as to the action taken in the matter'. ${ }^{48}$ A few persons attached to their proposal a self-addressed and stamped envelope to ensure a reply. The self-addressed envelopes were generally returned to them in the reply letter from the secretariat of the CA. The secretariat sent replies, mostly acknowledgements of receipt, to all senders and, in some instances, they answered with more detail. They did so promptly, sometimes within a couple of days. This, in itself, turned the writers into more than passive witnesses of constitution-making. The degree of engagement of the secretariat with the proposals they received would not, however, have been apparent to people.

The office of the constitutional adviser began to look into the pamphlets and publications relating to the CA that they received from various individuals and organizations in late November 1946. It is clear from the files that the secretariat did not expect this tide of proposals and memoranda. The assistant secretary, K. V. Padmanabhan, asked the research officer to have a first look at the proposals. A few days later, he submitted a note stating that

Suggestions regarding the future constitution of India would come from two sources: (1) associations or groups or individuals; (2) individual citizens. The former would generally take the form of representation for the recognition of certain claims. In other cases, it would be useful to prepare a summary of suggestions with particular reference to anything novel. ${ }^{49}$

The formal representations to the CA for the recognition of specific claims, it was decided, were to be handled by the general branch. Regarding the others, the research officer suggested that the research branch 'might be entrusted with the task of preparing a digest' ${ }^{50}$ There is evidence, on the basis of summary notes that the office prepared, that the secretariat held discussions on the proposals and memoranda that individuals and associations sent to the CA. The constitutional adviser also reviewed some of the proposals.

People's proposals were characterized by a sense of pragmatism. Most writers submitted suggestions based on practical goals, rather than the pursuit of abstract ideals. These future citizens recognized that a constitution was no

\footnotetext{
${ }^{46}$ For example, Satish C. H. Datta, 10 Mar. 1947, NAI, CA/19/47/1947 Cons I.

${ }^{47}$ Jagan Nath, Communal Harmony Board, to the secretary of the CA, 18 May 1947, s.n. 2, 20 May 1947, NAI, CA/19/47/1947 Cons I.

${ }^{48}$ The general secretary of the All-India Kayastha Conference, Lucknow, to Rajendra Prasad, 10 July 1947, NAI, CA/19/47/1947 Cons II.

${ }^{49}$ Office notes (office of the constitutional adviser), 27 Nov. 1946 - 4 Dec. 1946, NAI, CA/38/Gen/ 1946. Emphasis added.

${ }^{50}$ Research officer, 4 Dec. 1946, NAI, CA/38/Gen/1946.
} 
panacea for social change or for securing ideals. Thus, ahead of the debates in the $\mathrm{CA}$ on the interim report of the advisory committee on fundamental rights, Mr Batra commented about the abolition of untouchability that "[a] promise which can not be fulfilled in a reasonable time or a law which can not be respected should never be talked even'. ${ }^{51}$ A number of the proposals, therefore, aimed to offer, and often used the phrase, a workable constitution for India.

Proposals and schemes represented one form of engagement from below with the constitution-making. Groups' attempts to shape the constitution also manifested in their efforts to ensure safeguards and a voice for themselves. These dynamics gained momentum with the setting up of the important advisory committee on 24 January 1947, which stirred extensive responses and representations from the public.

\section{II}

The advisory committee was to report to the CA on fundamental rights, protection of minorities, and a scheme for the administration of tribal and excluded areas. The assembly decided that the committee would consist of no more than seventy-two members who could include persons who were not members of the assembly. The assembly elected on that day fifty members from the House and decided that the '[p]resident may at any time or at different times nominate members to the Committee not exceeding 22, 7 of whom shall be Muslims representing the Provinces of Madras, Bombay, the United Provinces, Bihar, the Central Provinces, Orissa and Assam. ${ }^{52}$

Realizing that Rajendra Prasad was vested with the power to appoint additional members to the advisory committee from outside the assembly, numerous organizations submitted their cases to him and appealed for a seat on the committee. Over the following month, the CA committee section received at least 150 representations of associations and individuals for either inclusion of their representatives in the advisory committee of the CA, and/or to be recognized statutorily as a minority community, which would entitle them to political, social, and cultural safeguards. ${ }^{53}$ Some request letters had already arrived at the CA from December 1946, before the advisory committee was set up. In particular, a number of tribal groups asked to be recognized as a 'distinct minority', and to secure, in advance, a seat on the advisory committee or in the CA. Moreover, organizations representing almost all major religious faiths made submissions.

A large number of Jain organizations sent telegrams and letters from across India to express their disappointment in seeing that there was not a single member of the Jain community in the advisory committee. They asked for at least one to be nominated. The president of a Jain organization from Delhi, for example, wrote that 'while communities numbering below two

\footnotetext{
${ }^{51}$ Beharilal Batra to Jawaharlal Nehru, 'Fundamental rights of man as a unit of the nation', 19 Apr. 1947, NAI, CA/19/47/1947 Cons I.

${ }^{52}$ CAD, 24 Jan. 1947. These were provinces where Muslims were in the minority.

${ }^{53}$ See, for example, the Assam Bengal Manipuri, 'An appeal to all political leaders who are engaged in framing the constitution of free India', 20 Dec. 1946, NAI, CA/27/COM/47 I.
} 
lacs $[200,000]$ are reported to be allotted three to four seats [it is] most regrettable that a minority of our standing and importance has been utterly neglected'. ${ }^{54}$ Organizations of other religious faiths, for example, the All India Conference of Indian Christians, the central Jewish board of Bombay, the Bengal Provincial Buddhist Association, and the All-India Momin Conference, also demanded representation in the committee and protection in the future constitution. They noted the importance of their community, their conditions, and contributions to India to justify their demands. ${ }^{55}$

Various caste, social, and professional organizations also fought for representation on the advisory committee and for constitutional protection on the basis of their distinct identities. There was an abundance of letters from numerous branches of the All India Gurkha League from across India. These local organizations held meetings and passed resolutions, which they sent to the CA. The All India Gurkha League Dibrugarh Branch, for example, demanded that Gurkhas be recognized as a minority community in view of the fact that the Gorkha community has its own culture, civilisation, manners and customs entirely different with the rest of India..$^{56}$ The national president of the All India Gurkha League wrote to Prasad: 'You must have realised that great injustice has been done to the Gorkhas. When 3 Parsis who number less than a lakh could be taken I do not see any reason why 3 Gorkhas cannot be taken to represent 30 Lakhs of Gorkha in India. ${ }^{57}$

The All India Kashap Rajput Maha Sabha wrote to Prasad: 'Our community is a backward minority in India educationally, economically, politically and socially, though its number ranges between 50 and 60 million spread all over the length and breadth of India. ${ }^{.58}$ They named sixteen groups under their community category. They explained that although they claimed a Rajput descent, they were not recognized as such by the high castes, and that they were treated as a low caste. They made their cause poignantly:

How to achieve our rightful place in the future Constitution or sovereign Republic of India, is a burning question that is agitating our mind, because we have no representatives of ours in the Constituent Assembly. Nobody else can gauge our feelings, our demands, safeguards and other things

\footnotetext{
${ }^{54}$ Chhogmal Chopra, president of the Shri Jain Swetambar Cerapanthi Sabha, Delhi Branch, to Govind Vallabh Pant, 23 Jan. 1947, NAI, CA/10/COM/47. At least thirty-two different Jain organizations sent similar letters.

${ }^{55}$ See the Catholic Union of India and the All India Council of Indian Christians, undated, 8 Feb. 1947 (discussed), NAI, CA/10/COM/47; the chairman of the central Jewish board of Bombay to Rajendra Prasad, president of the CA, 29 Jan. 1947, ibid.; the chairman of the central Jewish board of Bombay to the prime minister, government of Bombay, B. G. Kher, 14 Jan. 1947, ibid.; the Bengal Buddhist Association to the president of the CA, 5 Feb. 1947, ibid.; the vice president of the All-India Momin Conference, Allahabad, to the president of the CA, 27 Feb. 1947, NAI, $\mathrm{CA} / 34 / \mathrm{COM} / 47 \mathrm{I}$.

${ }^{56}$ All India Gurkha League, Dibrugarh Branch, Assam, 3 Feb. 1947 (received), NAI, CA/10/COM/47.

${ }^{57}$ The president of the All India Gurkha League to Rajendra Prasad, 30 Jan. 1947, NAI, CA/10/ $\mathrm{COM} / 47$.

${ }^{58}$ All India Kashap Rajput Maha Sabha, Lahore, to Rajendra Prasad, 1 Feb. 1947, NAI, CA/10/ $\mathrm{COM} / 47$.
} 
except our own representatives. This has necessitated us to demand seats. $^{59}$

In a similar vein, the Vanniakula Kashatrias from Madras, who described themselves as 'a very backward class', wrote that they 'feel that it is highly necessary to afford representation to...enable them to express their views and consent over the deliberations of the Sub-Committee that will be in charge of shaping the destinies of the minorities of this country'. ${ }^{60}$ To strengthen their case, they quoted from a speech of a member of the CA during the debate on the creation of the minorities sub-committee, about the need to "take particular care of the scheduled castes [former untouchables] and backward classes". ${ }^{61}$ Another group, the Backward and Minor Hindu Intermediate Allied Caste League, wrote to the president of the CA:

The new Constitution will undoubtedly safeguard the interests of the minor [sic] communities. But the Hindus as such are likely to be held as one community. But, Sir, you know that the Hindu Community is a heterogeneous community consisting of several major and minor communities having a separate social organic structure with a different social, religious and vocational standard only grouped together under a common federating name of Hindus. ${ }^{62}$

Some groups, for example, the Tea Garden Tribes and Castes of Assam, warned that they "have already begun to fear about their future and to decide not to recognise or obey the laws framed by the future Government that will be brought into being by the New Constitution that will be framed by the Constituent Assembly, unless they have reserved seats with definitely separate electorates'. ${ }^{63}$ In their calculation, as nearly two million backward people, they should have had two members in the CA.

By mid-February 1947, the CA secretariat sent acknowledgement of the receipt of letters or telegrams in connection with 'Representation on the Advisory Committee of the Constituent Assembly', which arrived between 21 January 1947 and 10 February 1947, to seventy-nine organizations and associations. ${ }^{64}$ The reply letters stated that the requests would be placed before the committee.

People and various organizations followed closely the early procedures and preparatory work of constitution-making at the CA. Some stated that they read about it in the press. ${ }^{65}$ Indeed, reports on the pending convening of the CA

${ }^{59}$ Ibid.

${ }^{60}$ The president of the Seventeenth Wallajah Vanniakula Kashatria Conference to Rajendra Prasad, 1 Feb. 1947 (received), NAI, CA/10/COM/47. Emphasis added.

${ }^{61}$ Ibid. They referred to a speech by Pandit Govinda Vallab Pant on 24 Jan. 1947.

62 The president of the Backward and Minor Hindu Intermediate Allied Caste League, Pune, to Rajendra Prasad, 5 June 1947, NAI, CA/34/1947-III. Emphasis added.

${ }^{63}$ Memorandum of the Tea Garden Tribes and Castes of Assam by the Assam Tea Labourers' Association to the CA, 6 Jan. 1947, p. 6, CA/27/COM/1947 I. Emphasis added.

${ }^{64}$ S. no. 58, 11 Feb. 1947, S. no. 18, 2 Feb. 1947, S. no. 10, 15 Feb. 1947, NAI, CA/10/COM/47.

${ }^{65}$ For example, Manik Chand Jain to Rajendra Prasad, 22 Jan. 1947, NAI, CA/10/COM/47; the secretary of God Sewak Sangh Mandla, Nagpur, 25 Jan. 1947, NAI, CA/27/Com/47 I. 
appeared in the press. ${ }^{66}$ Once the CA debates started, newspapers reported in detail key discussions of the assembly. They also provided helpful summaries, for example, under the heading 'Constituent Assembly snippets'. ${ }^{67}$ People followed these reports on the debates and on the assembly's decisions. This is clear from letters that arrived at the CA. Thus, Mr Manik Chand Jain, an advocate from Lucknow, wrote to Rajendra Prasad on 22 January 1947, commenting on and criticizing parts of his statement in the CA. ${ }^{68}$ Such public comments appeared more often in newspapers. For example, Mr Kewal Motwani from Bombay wrote to The Times of India: 'Sir, I think Dr. Sinha, the temporary Chairman of the Constituent Assembly was carried away by enthusiasm for his own idea of having a constitution reared for immortality and pitching upon the American one as the best model for us. ${ }^{69}$

All India Radio broadcast programmes on the assembly proceedings. Two days ahead of the beginning of the CA debates The Hindustan Times announced on its front page that 'At 8:30 pm on Monday, All India Radio, Delhi will bring a composite sound picture of the proceedings during the day. ${ }^{, 70}$

Moreover, a wide range of detailed and informative publications on various aspects of constitution-making, and later on the draft constitution, were also circulated at the time. For example, one day before the CA held its first meeting The Hindustan Times carried on its front page an advertisement announcing 'Just out: a guide to Constituent Assembly'. ${ }^{71}$ Sold for Rs.3.8, the guide included twenty-five documents related to the future constitution. Its appendices included a list of the members of the CA, key speeches and radio broadcasts by various leaders. ${ }^{72}$ A variety of books offered a broader historical and comparative perspective on India's constitutional moment: The Constituent Assembly of India; Constitutions of the world; The case for a Constituent Assembly for India: a historical and comparative study; Constituent Assembly for India; Indian Constituent Assembly; Constitution of India; Masses' memorandum on India polity; and Village republican union parliament. ${ }^{73}$ The proliferation of publications on the CA at the time, and the media's engagement with its work, intensified the public constitutional conversations outside Constitution Hall across the country.

\footnotetext{
${ }^{66}$ See, for example, 'Constituent Assembly to meet on Dec. 9: invitations issued to members', Hindustan Times (HT), 21 Nov. 1946, p. 1; 'Constituent Assembly: procedure for preliminary sitting', HT, 3 Dec. 1946, p. 3; 'Framers of India's constitution meet. proceedings suffer from lack of realism', TOI, 9 Dec. 1946, pp. 1, 5.

67 'Constituent Assembly snippets', HT, 11 Dec. 1946, p. 9.

${ }^{68}$ Manik Chand Jain to Rajendra Prasad, 22 Jan. 1947, NAI, CA/10/COM/1947.

${ }^{69}$ Kewal Motwani, 'The Swiss model for India', TOI, 14 Dec. 1946, p. 6.

${ }^{70}$ HT, 7 Dec.1946, p. 1.

${ }^{71}$ HT, 8 Dec. 1946, p. 1

${ }^{72}$ Moti Ram, ed., A guide to Constituent Assembly (New Delhi, 1946).

${ }^{73}$ A. C. Banerjee, The Constituent Assembly of India (Calcutta, 1947); B. Pattabhai Sitaramayya, Constitutions of the world (Lahore, 1946); M. Venkatarangaiya, The case for a Constituent Assembly for India: a historical and comparative study (Bombay, 1945); N. Gangulee, Constituent Assembly for India (London, 1942); Chanakkya, Indian Constituent Assembly (Bombay, 1947); Raja Mahendra Pratap, Constitution of India (Dehra Dun, 1946); Bhatt et al., Masses' memorandum on India polity (Bombay, 1946); Dr Moonji and Dr Dixit, Village republican union parliament (Bombay, 1946).
} 
When the Constituent Assembly elected the advisory committee, people and various organizations studied the list of the fifty elected members. They held meetings, conferences, and passed resolutions about it. On that basis, they calculated the ratio of representation of different groups in the committee in proportion to their share in the population. They claimed justice for themselves, and often put forward the names of persons that they sought to nominate to the advisory committee as their representatives. They reasoned their demands for representation and constitutional safeguards, invoking either their positive contribution to the defence of the country, to the economy, and mainly the social and economic backwardness of their caste community.

Some organizations wrote more than once and followed up on their original representations with more elaborated letters. A few organizations asked to send a deputation to Delhi so that the committee "learn at first hand...about our legitimate rights and claims'. ${ }^{74}$ Some organizations, among them tribal (adibasi) groups, also wrote with their demands directly to members of the minorities sub-committee, or advisory committee. ${ }^{75}$ Thus, various groups pursued forcefully their constitutional claims. Heads of organizations, which represented large groups of people, stated explicitly their strong wish to have a say in the constitutional deliberations that would shape, in the words of one organization, 'the destinies of the minorities of this country. ${ }^{76}$ As the letters above suggest, people saw in the constitution a concrete tool rather than an abstract legal document that had a scope for improving their predicament. They wanted to have a say in its production.

As already noted, the fact that all people and organizations received acknowledgements of the receipt of their letters from the secretariat of the CA meant that they became, in some way, a part of the constitutional debates, even when the replies did not engage with their substantial suggestions. Their claims were officially recorded in the CA archive. The president of the assembly, Prasad, ultimately appointed at least three of the petitioners for a seat on the advisory committee: Seth Chhogmal Chopra, who wrote on behalf of the Jains, Abdul Qayumm Ansari from the All-India Momin Conference, and M. Ruthnaswami, who was proposed by the Catholic Union of India. ${ }^{77}$ What is more significant is that the demands for minority status and safeguards that numerous organizations submitted to the CA were laid out before the members of the advisory committee and the minorities sub-committee when they began their discussions.

The minorities sub-committee sat every day from 21 July 1947 to 27 July $1947 .^{78}$ Ahead of the first meeting on 19 July 1947, the secretary of the CA wrote to all members of the advisory committee with the details of the agenda.

\footnotetext{
${ }^{74}$ See, for example, the president of the South Indian Visvakarma Mahajana Conference Central Board, Udumalpet, to the minorities sub-committee of the CA, 27 Mar. 1947, NAI, CA/27/COM/47 III.

${ }^{75}$ For a few such memoranda, see NMML, C. Rajagopalachari papers, Vth instalment, F. 37/2.

${ }^{76}$ The president of the Seventeenth Wallajah Vanniakula Kashatria Conference to Rajendra Prasad, 1 Feb. 1947 (received), NAI, CA/10/COM/47.

${ }^{77}$ Note by H. V. R. Iengar to the advisory committee, 26 May 1947, NAI, CA/37/47 III; the Catholic Union of India to Rajendra Prasad, 7 Feb. 1947, CA/10/COM/47.

${ }^{78}$ S. no. 41 , 'Report of the minorities sub committee of the advisory committee', NAI, CA/37/47 III.
} 
Attached to this letter in the archival folder was an elaborate table entitled: 'List of associations and organizations which claim to be recognised as minorities' ${ }^{79}$ It consisted of four columns: serial number, name of association etc., nature of demand, and a column with the file and page number where the demand could be found. The CA ultimately settled the question of safeguards for minorities towards the end of the constitution-making process; and the reservations for minorities only on 26 May 1949. Until then, more organizations submitted additional claims and suggestions for the protection of minorities and their constitutional status.

It is beyond the remit of this article to examine how the CA ultimately settled these questions. But it is clear from the volume of interests and the interactions between various organizations and the CA that people and their demands were not and could not simply be ignored. The point here is that people and groups defined themselves and asserted, in effect, ownership of the constitution: they expressed disappointment in the CA's selection of members to the advisory committee; they demanded redress; they saw themselves as having the right of 'consent over the deliberations of the sub-committee, ${ }^{\prime 80}$ and some even threatened that without the demanded amendments they would not abide by the constitution.

On 10 October 1947, Rajendra Prasad wrote to the chairman of the drafting committee, B. R. Ambedkar, ahead of the committee's first meeting to discuss the October 1947 draft constitution prepared by the constitutional adviser, asking for the committee's opinion on the suggestion that 'the Draft Constitution [of 1947] should be published and copies should be made available to the public before it is put up for consideration by the Constituent Assembly at its next session'. ${ }^{81}$ Prasad wrote that '[i]t is desirable that the public should be kept informed about the shape that the constitution is taking. ${ }^{82}$ The drafting committee discussed the matter at the beginning of its first meeting on 27 October 1947. It decided not to publish the October draft constitution, but to publish the draft that the committee would settle. ${ }^{83}$

This was a departure from the original intent of some leading members of the CA. For example, in August 1946, shortly before the CA began its debates, K. M. Munshi, who would become a member of the fundamental rights subcommittee and the minorities sub-committee, was asked in an interview "what was the primary condition for success of the Constituent Assembly'. ${ }^{84}$ He said 'that the first condition was that its proceedings should be held in camera "and that the Indian press and the world press should contribute to its success by keeping silent"". 85 This was generally in line with the accepted

\footnotetext{
79 'List of associations and organizations which claim to be recognised as minorities' (date illegible), NAI, CA/37/47 III). The folder contains only the first page of the table, which lists a summary of the demands of fourteen organizations, some of which are mentioned above.

${ }^{80}$ The president of the Seventeenth Wallajah Vanniakula Kashatria Conference to Rajendra Prasad, 1 Feb. 1947 (received), NAI, CA/10/COM/47.

${ }^{81}$ B. Shiva Rao, The framing of India's constitution (5 vols., Nasik, 1968), III, p. 319.

82 Ibid.

${ }^{83}$ Ibid., p. 317.

84 'Constitution body “must succeed”: Mr. Munshi’s views', TOI, 5 Aug. 1946.

85 Ibid.
} 


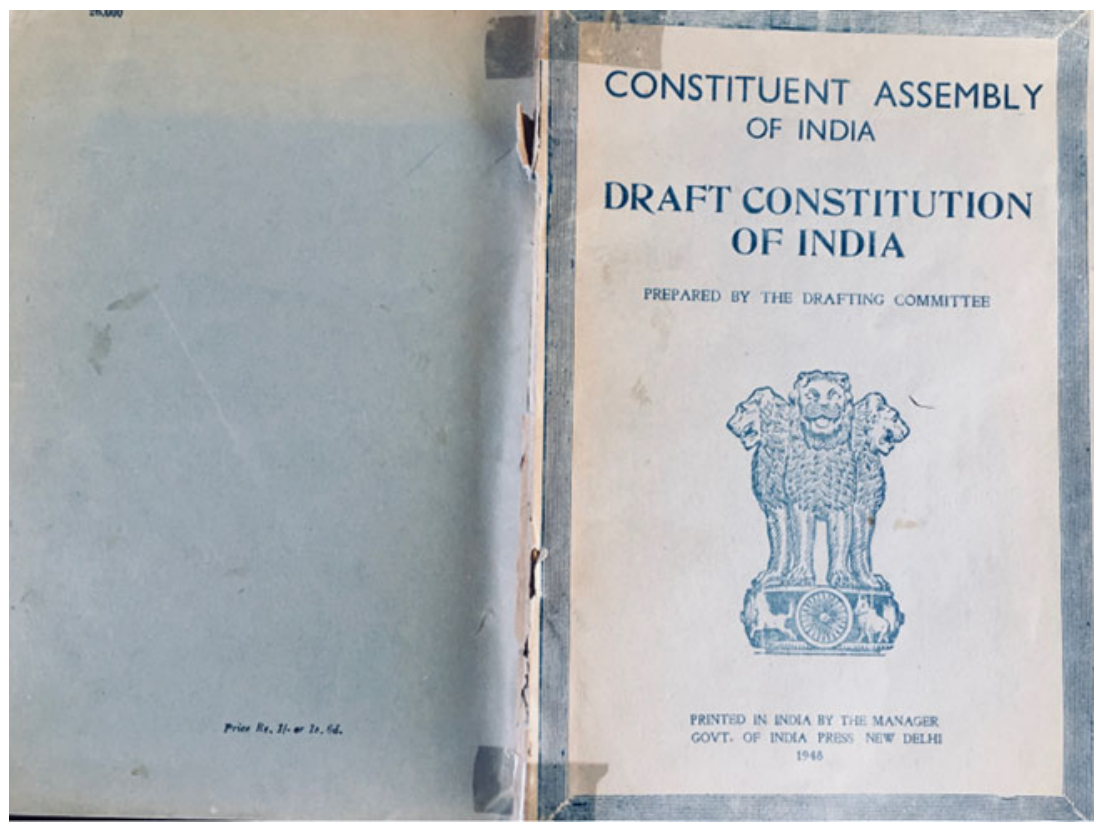

Figure I. The February 1948 draft constitution that was sold to the public for Rs.I.

wisdom of the time that constitutions should be best written by experts behind closed doors. Prasad's request and the decision to publish the draft constitution, inviting would-be sovereigns to submit their views and suggestions, only came after they had already received dozens of letters of this kind. It is, therefore, likely that the initiative to publish the draft constitution and to open it up for wider public consultation was at least in part a response to people's engagements with the making of the constitution.

The February 1948 draft constitution of India that was prepared by the drafting committee was published and given wide publicity. Copies of it were sold for the price of only Rs.1 (Figure 1). The government invited comments from a wide range of bodies and from the public. This, and the on-going interactions of a large number of diverse groups claiming identity recognition, safeguards, and a seat on the committee that was to make recommendations on these issues, gave some tangible appearance to the forming new constitutional order wherein sovereignty was to be derived from the people. The publication of the draft, indeed, elicited considerable response. ${ }^{86}$ By then, the place of the people in the constitution was apparent, and public discussions about a constitution for India were in vogue.

${ }^{86}$ This article, as already mentioned, focuses on the early stages of the constitution-making process, until the February draft was published. See Rao, The framing of India's constitution, IV, pp. 3-4. 
People's imaginative concerns animated the making of the constitution far beyond what we have been accustomed to assume about India. People engaged with the constitution both by making practical suggestions and by discussing its ideals and goals. They were invested in thinking about possible visions for the future constitution and acted on their ideas and interests by writing and sending proposals for the constitution to the CA. Moreover, people made efforts to participate and have a say in the process of determining the constitutional scope for inclusion, for minority rights and safeguards. They made representations in an attempt to shape the constitution and derive benefits from it. People were also in tune with the process of constitution-making. They wrote about it and responded in real time to topics the CA was debating. In doing all this, people spoke iteratively about means of securing democracy, about the unity of India, about a workable constitution, universal franchise, and about their rights. The language of the constitution became widely shared. People also expressed their emotions about the constitution. The question of minority safeguards, for example, was 'agitating' their minds. ${ }^{87}$

In this process, people attached value to the idea of a constitution for India. Their efforts to take an active part in its production were registered officially in the form of the acknowledgements of the receipts of their proposals and letters received; in the tabulated summaries of their claims to be recognized as minorities that were laid before the members of the assembly's minorities subcommittee; and ultimately in the CA's archival records. The constitution was to be enacted in the people's name. By engaging in the process of its making they made it their own. While these people were not as such a reflection of 'the people', the outpouring of constitutional discourses, people's organic and often spontaneous interactions with the constitution-making from below, and the language they produced played a role in the creation of the people and in grounding the notion of a constitution derived from their will. ${ }^{88}$

Whereas some of the letter writers belonged to the elite and their proposals reflected part of the structures of exclusion and of safeguarding privileges, others were part of groups from the social and territorial margins. Women and Muslims were notably largely absent from the archive. We know little about these people. But we do know that they were from across the country. And that even as elites from marginal groups, they claimed to write on behalf of large numbers of people, sometimes tens of thousands, and up to millions of people who were far removed from the elites responsible for drafting the constitution. The fact, as Rohit De shows in A people's constitution, that members of these groups used the constitution to find

\footnotetext{
${ }^{87}$ All India Kashap Rajput Maha Sabha, Lahore, to Rajendra Prasad, 1 Feb. 1947, NAI, CA/10/ $\mathrm{COM} / 47$.

${ }^{88}$ For explorations of the concept of 'the people', and of 'we the people' in the context of India's transition to independence, see David Gilmartin, "Election law and the "people" in colonial and postcolonial India', in Dipesh Chakrabarty, Rochona Majumdar, and Andrew Sartori, eds., From the colonial to the postcolonial: India and Pakistan in transition (New Delhi, 2007), pp. 89-55; Kalyani Ramnath, "We the people": seamless webs and social revolution in India's constitutional assembly debates', in Bhatia, ed., The Indian Constituent Assembly, pp. 181-95.
} 
solutions to their specific grievances as soon as it came into force, suggests that the people's sentiments and sense of ownership of the constitution and its making extended beyond narrow elites. ${ }^{89}$

People's and groups' engagements with the making of the constitution from below mirrored a ground reality of multifarious fractured and sometimes newly formed groups that could not be simply bound around common language, culture, religion, or ethnicity. The lived reality they made visible in their interactions with the CA did not easily fit in with commonly conceived or colonial ideas of social and political formations, such as the 'Great Hindu Community'. ${ }^{90}$ Instead, they perceived of themselves as "communities having a separate social organic structure with a different social, religious and vocational standard only grouped together under a common federating name of Hindus. ${ }^{91}$ While they saw the constitution as a tool to secure their rights as communities, they were also sceptical about it. Paradoxically, the concurrent proposals and demands for representation made by so many different groups contributed to producing a sense of universality - a universe of minorities. The engagements of diverse groups with constitutionmaking from below and the impartial responses from the CA served to legitimate the constitution and the newly forming power structure. It also had implications for forming the distinct character of the Indian constitution, which ultimately produced a framework within which individual rights and group rights, and different conceptions of equality and secularism, would cohabit. The constitution, thus, did not resolve the contending views and tensions around these issues, but it was nonetheless able to produce a legal and political space to contain the conflictual nature of Indian society. This made it a good fit for Indians' lived reality. In turn, this contributed to the institutionalization, and the endurance, of the forming constitutional order. Democracy would become a real open-ended affair, which also meant that it could fail.

People's mounting pressures on the office of the CA secretariat and the president, as well as the growing constitutional talk among the public, created a kind of fever of constitutional expectations that accompanied the making of the constitution from the early stages. That people acted as unsolicited citizens, as sovereign-subjects in their engagement with the constitution-making, became part of the theatricality that was constitutive of 'the people', and that made it real. In that sense, people's engagements with the constitution-making from below became part of the process of decolonization, wherein Indians reconstituted themselves as free subjects and as self-rulers. In conventional narratives, constitution-making in the context of decolonization has been understood as a process controlled by both foreign and local elites. ${ }^{92}$ The uniquely Indian drama of constitution-making, wherein the people had a

\footnotetext{
${ }^{89}$ De, A people's constitution.

${ }^{90}$ The general secretary of the All India Kashyup Rajput Golden Jubilee Conference, Jullundar, to Rajendra Prasad, 10 Feb. 1947, NAI, CA/10/COM/47.

${ }^{91}$ The president of the Backward and Minor Hindu Intermediate Allied Caste League, Pune, to Rajendra Prasad, 5 June 1947, NAI, CA/34/1947-III.

${ }^{92}$ See, for example, H. Kumarasingham, 'Eastminster-decolonisation and state-building in British Asia', in H. Kumarasingham, ed., Constitution-making in Asia: decolonisation and state-building in the aftermath of the British empire (London, 2016), pp. 1-35.
} 
visible role on the stage, presents a different picture of constitution-making. The emerging political imaginary of popular sovereignty, driven by these processes, made the shift to democracy at its inception in India succeed.

Acknowledgements. For their research assistance, I thank Ayesha Sheth, Juhi Mendiratta, and Srotoswini Sharma. I presented early drafts of this essay at the 'South Asia Legal Studies Workshop', University of Madison, Wisconsin; 'India and Pakistan: The Formative Phase, 1947-c. 1960', University of London; 'India: Seventy Years of the Republic', New Zealand India Research Institute, Victoria University of Wellington; the Centre of South Asian Studies Seminar, University of Cambridge; 'The People's State', University of Copenhagen; and at the Centre for Modern Indian Studies Colloquium, University of Göttingen. I thank the organizers and participants of these conferences and seminars. I particularly thank Tarunabh Khaitan, Rohit De, and Fredrik Galtung for their comments on the early draft, and Michael Zakim for valuable suggestions. I also thank the two anonymous reviewers of the Historical Journal for their comments and suggestions, and Rachel Leow, the journal's Co-Editor, who provided additional and very helpful suggestions.

Funding Statement. Research for this article was supported by the Israel Science Foundation (Grant no. 1153/14).

Cite this article: Shani O (2022). The People and the Making of India's Constitution. The Historical Journal 65, 1102-1123. https://doi.org/10.1017/S0018246X21000856 